\title{
Evaluation of the knowledge regarding vitamin $D$, and sunscreen use of female adolescents in Iran
}

\author{
Afsane Bahrami ${ }^{1,2}$, Zahra Farjami ${ }^{3}$, Gordon A. Ferns ${ }^{4}$, Parichehr Hanachi ${ }^{*^{* \dagger}}$ and Majid Ghayour Mobarhan ${ }^{3^{*}+}$
}

\begin{abstract}
Background: Vitamin D (Vit D) deficiency/insufficiency is an important risk factor for several chronic conditions. We aimed to evaluate the knowledge and behavior of female adolescents with respect to the association between sunlight exposure, sunscreen use, and Vit D status.

Methods: This cross-sectional survey was performed in northeastern Iran, among 940 female adolescents in January 2015. Each subject completed a questionnaire containing items about demographic characteristics, knowledge about Vit D and their use of sunscreen. Serum Vit D levels were measured using an electrochemiluminescence method and dietary intake of Vit D was assessed using a Food Frequency Questionnaire. Statistical analyses were conducted using SPSS software. A $P$ value $<0.05$ was considered statistically significant.

Results: Few of the participants were aware of the biological functions of Vit $D(8.8 \%)$, the causes of Vit D deficiency (16.7\%), and the sources of Vit D (9.3\%). Less than half of the participants used sunscreen during the day. The serum levels of Vit $D$ in subjects who used sunscreen were significantly lower than those who did not $(p=$ 0.004). However, there was no significant association between their knowledge about Vit $D$ and serum Vit $D$, or dietary intake of Vit D.

Conclusion: There appears to be a lack of coherence between lifestyle, behavior and knowledge that may affect the Vit D status of adolescent girls in northeastern Iran. This information provides a basis for developing public health planning (workshops or training at the college level) for the prevention of Vit D deficiency especially in adolescent girls.
\end{abstract}

Keywords: Vitamin D, Sun-screening agents, Knowledge, Behavior, Diet

\footnotetext{
* Correspondence: p.hanachi@alzahra.ac.ir; GhayourM@mums.ac.ir

${ }^{\dagger}$ Parichehr Hanachi and Majid Ghayour Mobarhan contributed equally to this work.

${ }^{5}$ Department of Biotechnology, Faculty of Biological Science, Alzahra University, Tehran, Iran

${ }^{3}$ Metabolic Syndrome Research Center, Mashhad University of Medical Sciences, Mashhad, Iran

Full list of author information is available at the end of the article
}

(c) The Author(s). 2021 Open Access This article is licensed under a Creative Commons Attribution 4.0 International License, which permits use, sharing, adaptation, distribution and reproduction in any medium or format, as long as you give appropriate credit to the original author(s) and the source, provide a link to the Creative Commons licence, and indicate if changes were made. The images or other third party material in this article are included in the article's Creative Commons licence, unless indicated otherwise in a credit line to the material. If material is not included in the article's Creative Commons licence and your intended use is not permitted by statutory regulation or exceeds the permitted use, you will need to obtain permission directly from the copyright holder. To view a copy of this licence, visit http://creativecommons.org/licenses/by/4.0/ The Creative Commons Public Domain Dedication waiver (http://creativecommons.org/publicdomain/zero/1.0/) applies to the data made available in this article, unless otherwise stated in a credit line to the data. 


\section{Background}

Vitamin D (Vit D) has an important role in bone health, calcium homeostasis and immune regulation $[1,2]$. Furthermore, Vit D deficiency may enhance the risk of cancer, diabetes mellitus types 1 and 2, tuberculosis and cardiovascular disease [3]. Deficiency of Vit D is also positively associated with the morbidity from several conditions, that include: cardiovascular disease, diabetes, obesity and autoimmune diseases [4-7]. Vit D deficiency is common in many developing countries [8]. Whilst several chronic diseases are associated with Vit D insufficiency, patients with adequate levels of Vit $\mathrm{D}$ have been shown to have better health outcomes [9]. In Asian countries, the risk of Vit D deficiency may be underestimated as it may be taken for granted that individuals receive sunshine throughout the year. However, Vit D status has been shown to be compromised in Middle Eastern countries despite the intense prevailing sunshine [10]. The prevalence of Vit D deficiency in China, Turkey, India, Iran, and Saudi Arabia, has been estimated to be $30-93 \%$ over the last 2 decades [11].

Several factors may affect the prevalence of Vit D deficiency, including latitude, duration of sun exposure, clothing, season and skin pigmentation [12]. Fair skin is favored among Asian women; in addition, they believe that sunlight affects skin wrinkling and skin pigmentation. Deficiency of Vit D is very common in India, and Vit D deficiency is prevalent in tropical countries overall [13].

A recent study demonstrated a high frequency of Vit D insufficiency among Iranians [11] and this is also true for the neighboring countries despite their ample sunlight [14] with a prevalence of reaching $85 \%$ in some regions [15]. The time spent outside of the home, and exposure to sunlight, have fallen in Iran due to urbanization, changes in lifestyle and, technology, and rising temperatures [16-18]. In addition, there have been changes in dietary habits, especially in the younger generations. Iranian women often cover their body, shielding their skin from sunlight, and this may also contribute to Vit D deficiency [19]. On the other hand, exposure to ultraviolet (UV) radiation in sunlight may increase the risk of skin cancer; the incidence rate of this cancer is 10.13 to 28.1 per 100,000 people In Iranian population $[20,21]$ which is lower than in Australia, Norway and Denmark (33.6, 29.6 and 27.6 per 100,000 people respectively) [22]. Another source of Vit D is fortification or supplementation [23]. Government recommendations in Iran have suggested using 50,000 IU vitamin D3 supplement per month for adult (19-59 years) in order to prevent vitamin D deficiency [24].

The knowledge, and behaviors of the population with respect to Vit D, may play an important role in the prevention of chronic disease. In the Iranian population, young girls are at a particularly high risk of Vit D deficiency [19], due to their tendency to shield themselves from exposure to the sun and cover their face, hands with protective sunscreen creams.

There is evidence for a lack of basic awareness of the role and importance of Vit D globally [25-27]. There have been no reports with respect to the knowledge of the importance of Vit D amongst adolescent females in Iran. The aim of this study was to investigate the behavior, and knowledge of Iranian adolescent girls with respect to sunscreen, Vit D and its importance to health.

\section{Methods}

\section{Population study}

This cross-sectional study among adolescent girls was performed in Mashhad and Sabzevar, two cities in Iran as described previously [28, 29]. Briefly, the population samples were recruited from 6 different geographic areas in 2 cities in January 2015, using a multistage cluster randomized sampling approach. Four high schools from each of the 6 geographic areas were chosen, and 1 class from each grade (3 classrooms from each school) was randomly selected for inclusion. In each classroom, approximately 15 students were included. Schools, classes and students were recruited using computer-generated random numbers. Inclusion criteria were: an age of between 12 and 19 years, single, and apparent healthy status. We excluded those with any acute or chronic diseases, as well as girls who were receiving antiinflammatory, antidepressant, antidiabetic or antiobesity drugs, Vit D or calcium supplement use, and hormone therapy within the previous 6 months. A total of 1026 subjects were initially approached, of whom 956 met the inclusion criteria. The Ethics Committee of the Mashhad University Medical School approved the study (IR. MUMS.fm. REC.1395.12). Written consent was obtained from students and their parents.

\section{Data collection instruments}

The questionnaire comprised of 3 sections (Supplementary File 1). Section 1 comprised demographic information of the participants such as family members, type of house and rooms they inhabited, the occupation of their parents and their educational attainment using a standard questionnaire which was previously validated in the PIRLS for Iran [30, 31]. Section 2 was concerning behavior towards the usage of sunscreen. This section including items exploring the frequency, seasons, amount and the location as well as sun protection factor (SPF) of sunscreen usage. Section 3 was designed to evaluate their knowledge on Vit D, and comprised 5 questions: on the role of Vit D in the body, the main sources of Vit $D$, factors that cause Vit D deficiency and related diseases such as osteoporosis; the questionnaire was 
previously developed by Kung et al., in Hong Kong and was translated into Persian [25]. The questionnaire was completed in the presence of the researcher to prevent the use of the internet, or mobile phones to access information. We assessed test-retest reliability of the questionnaire in a sample of 20 individuals, with a 2 weeks interval between the tests. Test-retest reliability and validity of this questionnaire (range of intra-class correlation coefficient for three sections is $0.73-0.96$ and Cronbach's Alpha was 0.71-0.88) was established for this population.

A validated food frequency questionnaire (FFQ) was used to assess dietary intakes, and was validated for the Iranian population in a previous study [32-34]. The questionnaire included 65 food items with 5 frequency categories (frequency of intake: daily, weekly, monthly, rarely, and never) for each food item and portion size. To calculate energy and nutrient intakes, the reported portion size in FFQ were converted to grams by using household measures and subsequently were entered into the Nutritionist IV software for analysis.

\section{Evaluation of vitamin D levels}

Fasting blood samples were obtained early in the morning following a $12 \mathrm{~h}$ overnight fast. Blood samples were immediately centrifuged to separate serum and samples were stored at $-80^{\circ} \mathrm{C}$ at the reference laboratory. An electrochemiluminescence method (ECL, Roche, Switzerland) was used for the measurement of serum 25-hydroxy vitamin D (25OHD) concentrations.

\section{Data analysis}

A Kolmogrov-Smirnov test was used to assess the normality of the distribution of variables. Descriptive statistics such as means and standard deviations (for normally distributed data) or median and interquartile range (IQR) (for non-normally distributed data) as well as frequency and percentages are provided. For normally distributed variables, independent sample T-test or oneway ANOVA test and for non-normally distributed variables, the Mann-Whitney test or Kruskal-Wallis test were used. A $P$ value $<0.05$ was considered statistically significant. Statistical analyses were performed by SPSS version 16.0 (SPSS Inc., Chicago, Ill., USA).

\section{Results}

The socio-demographic characteristics in relation to serum Vit D levels of the participants are shown in Table 1. The mean age of participants was $14.6 \pm 1.5$ (range: 12 to 18 ) years. Eight hundred and ninthly seven (95.4\%) of them had reached the age of menstruation and puberty. Serum Vit D levels were not related to attainment of puberty, other family members sharing their room, or having an exclusive room, parental divorce, as well as mother/father occupations and educational attainment $(P>0.05)$. However, girls who were orphans had a significantly lower serum Vit D levels compared to other groups $(p=0.019)$.

\section{Knowledge of the participants about Vit D}

A significant number of participants (39.4\%) stated that they were aware about the role of Vit D and few participants $(8.8 \%)$ stated that they were completely aware about the role of Vit D. When asked about the causes of Vit D deficiency, 30.7\% of participants were somewhat aware of these causes, whereas, $16.7 \%$ of participants were completely aware about the causes of deficiency of Vit D and $52.6 \%$ of participants did not know about the health impact of a reduction of Vit D status. Although, Vit D has been important role in bone health and osteoporosis, $74.5 \%$ of the participants did not know about the role of Vit D in osteoporosis. Overall, there was no significant association with the knowledge of the participants about Vit $\mathrm{D}$ and its serum levels and dietary intake $(P>0.05$; Table 2).

\section{Behavior toward sunlight and sunscreen usage of participant}

Girls who used sunscreen were more likely to be deficient in Vit D compared to individuals who did not use sunscreen $(P=0.004$; Fig. 1$)$. Approximately $30.42 \%$ of participants reported that they used sunscreens only in the morning, $13.72 \%$ twice a day, $2.76 \%$ three times a day and half of the participants $53.1 \%$ reported that they had never used sunscreens (Table 3). Among sunscreen users, levels of Vit D were not significantly associated with the frequency, amount, SPF, of the sunscreen used, nor the season and location $(P>0.05$; Table 3$)$.

\section{Discussion}

This is the first study to evaluate the knowledge, and some behaviors that affect Vit D status among female adolescents in northeastern Iran. We found that knowledge about Vit D in young women and girls from Mashhad and Sabzevar in Iran is very limited, and approximately half of the population did not know about the role of Vit D in health and disease. According to recent studies, Vit $\mathrm{D}$ deficiency has been shown in many Asian countries [35, 36]. The role of Vit D is especially important in adolescent girls; since Vit D status affected all aspects of growth, development and puberty in this age [37]. Our study suggests that a majority of our population may be deficient for Vit D.

In addition, few students were aware of the causes of Vit D deficiency (16.7\%), the main sources of Vit D and the required time to spend outside to get adequate Vit D level (9.3\%). This lack of knowledge about the sources of Vit D and causes of deficiency is a major concern. In 
Table 1 Demographic and clinical characteristics of the participant $(N=940)$

\begin{tabular}{ll}
\hline Variables & Number (\%) \\
\hline $\begin{array}{l}\text { Puberty } \\
\text { Yes }\end{array}$ & $897(95.4)$ \\
No & $43(4.6)$ \\
Family members & \\
$2-4$ & $447(47.55)$ \\
$5-7$ & $458(48.68)$ \\
$8-10$ & $29(3.11)$ \\
$>11$ & $6(0.66)$
\end{tabular}

Vitamin D level* $(\mathrm{ng} / \mathrm{ml})$

P value ${ }^{* *}$

Roommate

Father and mother

864 (91.98)

$6.8(4.0-9.9)$

Father

9 (0.94)

57 (6.04)

$6.5(4.1-11.0)$

Mother

$10(1.04)$

$6.7(3.8-9.8)$

0.247

Other family

$6.6(4.1-10.1)$

$8.0(4.7-10.4)$

$9.1(6.0-16.0)$

Exclusive room

$\begin{array}{ll}\text { Yes } & 498(52.95) \\ \text { No } & 442(47.05)\end{array}$

$6.7(4.0-10.2)$

$5.4(3.5-9.6)$

$6.7(3.7-9.0)$

$8.4(7.5-37.4)$

Parental death

Yes

40 (4.21)

$6.8(4.2-10.5)$

0.209

No

900 (95.79)

$4.3(3.6-7.9)$

0.019

Parental divorce

Yes

41 (4.51)

$6.7(4.1-10.2)$

No

899 (95.49)

$6.4(4.5-10.1)$

Paternal Occupation

Worker
Employee
Tradesmen market
Spiritual
Other
Deceased

$320(34.00)$

$6.7(4.0-10.1)$

169 (17.96)

$6.9(4.6-9.4)$

0.363

186 (19.79)

$6.7(4.0-11.9)$

$6.7(3.6-10.3)$

7 (0.77)

$8.1(5.6-20.0)$

254 (27.09)

$6.5(3.7-9.5)$

$4(0.38)$

$8.1(4.9-17.8)$

Maternal Occupation

$\begin{array}{ll}\text { Worker } & 8(0.85) \\ \text { Employee } & 38(4.08) \\ \text { Housewife } & 812(86.35) \\ \text { other } & 77(8.25) \\ \text { Deceased } & 5(0.47)\end{array}$

$6.5(3.6-9.1)$

0.668

$6.2(3.0-10.1)$

$6.8(4.0-10.2)$

$6.5(4.3-9.4)$

$4.5(3.0-6.0)$

Educational attainment of father (year)

$\begin{array}{ll}0-9 & 372(39.6) \\ 10-12 & 438(46.6) \\ \geq 13 & 129(13.8)\end{array}$

$6.5(4.0-9.0)$

0.103

$6.9(3.9-10.2)$

$7.1(4.3-15.9)$

Educational attainment of mother (year)

$0-9$

$448(47.66)$

$5.2(3.0-10.0)$

0.168

$10-12$

$362(38.51)$

$6.6(4.0-10.2)$

130 (13.83)

$7.2(4.5-10.4)$

*Vitamin D levels expressed as median (interquartile range)

${ }^{*}$ By using Mann-Whitney test or Kruskal-Wallis test 
Table 2 Knowledge of the participants about Vitamin D $(N=940)$

\begin{tabular}{|c|c|c|c|c|}
\hline Questions & & $\begin{array}{l}\text { Completely } \\
\text { aware }\end{array}$ & $\begin{array}{l}\text { Somewhat } \\
\text { aware }\end{array}$ & Don't know \\
\hline $\begin{array}{l}\text { Role of vitamin D in the body } \\
\text { Correct answer: }\end{array}$ & N (\%) & $83(8.8 \%)$ & $370(39.4 \%)$ & $487(51.8 \%)$ \\
\hline -bone health, calcium absorption & $\begin{array}{l}\text { Vitamin D level } \\
\text { (ng/ml) }\end{array}$ & $6.8(3.9-13.7)$ & $6.4(3.7-9.9)$ & $\begin{array}{l}7.0(4.3- \\
9.9)^{\mathrm{NS}}\end{array}$ \\
\hline $\begin{array}{l}\text {-prevention of many chronic illnesses (i.e. cancer, diabetes, stroke, arthritis, and } \\
\text { high blood pressure) }\end{array}$ & $\begin{array}{l}\text { Vitamin D intake } \\
(\mu \mathrm{g})\end{array}$ & $3.0 \pm 1.4$ & $3.1 \pm 1.8$ & $3.2 \pm 1.8 \mathrm{NS}$ \\
\hline $\begin{array}{l}\text { Cause of vitamin D deficiency } \\
\text { Correct answer: }\end{array}$ & N (\%) & $157(16.7 \%)$ & $289(30.7 \%)$ & $494(52.6 \%)$ \\
\hline -Limited sunlight exposure (Full time indoor occupation) & $\begin{array}{l}\text { Vitamin D level } \\
(\mathrm{ng} / \mathrm{ml})\end{array}$ & $6.9(4.5-10.5)$ & $6.8(4.0-11.9)$ & $\begin{array}{l}6.5(3.7-9.3) \\
\text { NS }\end{array}$ \\
\hline -Lack of dietary vitamin $D$ food intake & $\begin{array}{l}\text { Vitamin D intake } \\
(\mu \mathrm{g})\end{array}$ & $3.3 \pm 1.7$ & $3.2 \pm 1.8$ & $3.1 \pm 1.8^{\mathrm{NS}}$ \\
\hline $\begin{array}{l}\text { Related disease? } \\
\text { Correct answer: }\end{array}$ & N (\%) & $105(11.2 \%)$ & $382(40.6 \%)$ & $453(48.2 \%)$ \\
\hline - Osteomalacia, rickets & $\begin{array}{l}\text { Vitamin D level } \\
(\mathrm{ng} / \mathrm{ml})\end{array}$ & $6.6(4.4-13.5)$ & $6.7(4.1-10.0)$ & $\begin{array}{l}6.8(3.8-9.9) \\
\text { NS }\end{array}$ \\
\hline -Osteoporosis and bone fractures & $\begin{array}{l}\text { Vitamin D intake } \\
(\mu \mathrm{g})\end{array}$ & $3.3 \pm 1.9$ & $3.0 \pm 1.7$ & $3.2 \pm 1.8^{\mathrm{NS}}$ \\
\hline $\begin{array}{l}\text { Food sources of vitamin D } \\
\text { Correct answer: }\end{array}$ & $N(\%)$ & $87(9.3 \%)$ & $369(39.3 \%)$ & $483(51.4 \%)$ \\
\hline $\begin{array}{l}\text { - Sea food (fish, shrimps, tuna, etc.), egg yolk, liver } \\
\text {-Dairy products (milk, cheese, }\end{array}$ & $\begin{array}{l}\text { Vitamin D level } \\
(\mathrm{ng} / \mathrm{ml})\end{array}$ & $6.6(4.3-11.7)$ & $6.6(4.1-10.3)$ & $\begin{array}{l}6.8(3.9-9.9) \\
\text { NS }\end{array}$ \\
\hline yogurt, etc. ...), breakfast cereals & $\begin{array}{l}\text { Vitamin D intake } \\
(\mu \mathrm{g})\end{array}$ & $3.2 \pm 2.3$ & $3.0 \pm 1.8$ & $3.3 \pm 1.7^{\mathrm{NS}}$ \\
\hline $\begin{array}{l}\text { Familiar with the term "osteoporosis" and preventive } \\
\text { strategies } \\
\text { Correct answer: }\end{array}$ & N (\%) & $70(7.5 \%)$ & $169(18.0 \%)$ & $701(74.5 \%)$ \\
\hline - weakening of bones, which increases risk of fractures & $\begin{array}{l}\text { Vitamin D level } \\
(\mathrm{ng} / \mathrm{ml})\end{array}$ & $6.6(4.5-12.7)$ & $6.5(4.0-9.3)$ & $\begin{array}{l}6.9(3.9- \\
10.2)^{\text {NS }}\end{array}$ \\
\hline - Prevented by eating calcium and vitamin D-rich foods, exercise & $\begin{array}{l}\text { Vitamin D intake } \\
(\mu \mathrm{g})\end{array}$ & $3.2 \pm 2.0$ & $3.4 \pm 2.2$ & $3.1 \pm 1.7^{\mathrm{NS}}$ \\
\hline
\end{tabular}

Serum vitamin D levels expressed as median (IQR) and compared in three groups by using Kruskal-Wallis test

Vitamin $D$ intake expressed as mean \pm SD and compared in three groups by using one-way ANOVA test. NS: Non-significant ( $p>0.05)$

* For each question, answer one item and both items considered as "Somewhat aware" and "Completely aware", respectively

various other studies, different levels of knowledge about Vit $D$ have been reported. The majority of Indian $(53.3 \%)$ students knew that sunlight is the main source of Vit D [26]. In one study among Omani female university students, about $90 \%$ of responders were aware of Vit $\mathrm{D}$ and sunlight as its most important source [38].

In a survey among private university students in Malaysia aged between 16 and 30 years old, only $7.2 \%$ of the respondents reported that they did not know from where Vit D is derived, whereas $69.2 \%$ of participants properly identified sunlight as an important contributor [39]. In all of these studies, participants were university students, studying at a tertiary level, and would therefore be expected to have a good knowledge of health issues compared to our sample population.

In a recent investigation among young student (aged 18-25 years) in Pakistan, only 9\% of individuals were able to identify the correct food sources of Vit D, 33\% were aware of the bone health advantages of Vit D and $36 \%$ knew that sunlight exposure was a major factor affecting Vit D synthesis in body [40]. Also, knowledge about Vit D, its sources and health benefits was very limited (28.8\%) in Emirati and International tourist students in Dubai [41].

Another important finding of this study was that $46.9 \%$ of girls never used sunscreens, different to the findings within a study cohort in Hong Kong in which reported $44.4 \%$ of middle-aged and elderly women used a parasol to shade themselves from the sun, but the majority $(81.2 \%)$ did not use sunscreen products [25]. However, two reports from Saudi Arabia and Vietnam reported a higher use of sunscreen particularly in females [42, 43].

Due to the sunny weather in most seasons of year in Iran; sunscreen usage is the most efficacious way for protection of the skin from sunlight over-exposure. We 


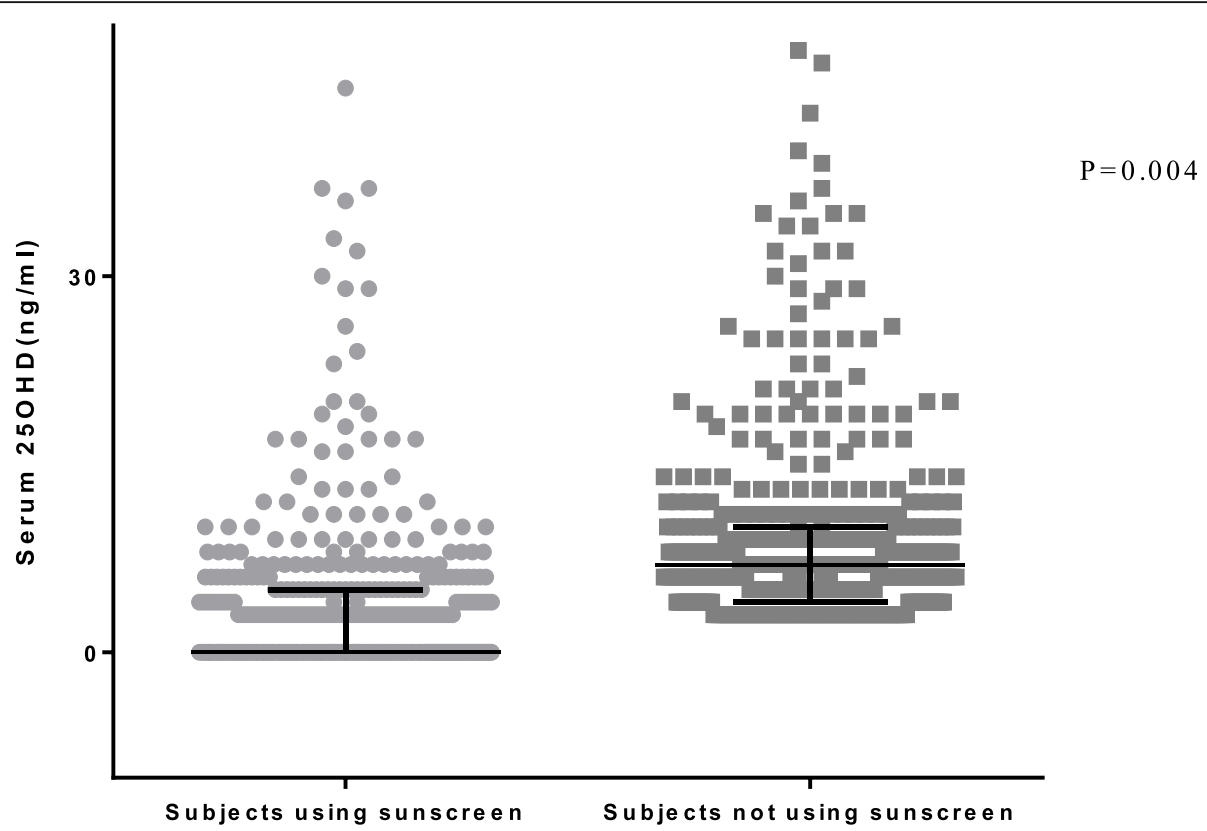

Fig. 1 Individuals who used sunscreen compared to individuals who did not use sun screen are more likely to be deficient in Vit D. Median (interquartile range; IQR) of 25-hydroxyvitamin D levels were 6.1(3.7-9.2) $\mathrm{ng} / \mathrm{ml}$ in sunscreen user individuals $(n=441), 7.3(4.4-10.7) \mathrm{ng} / \mathrm{ml}$ in $\mathrm{non}$ sunscreen users $(n=449)$. Bars indicate IQR. $p=0.004$; Mann-Whitney test

did not explore the reasons for this behavior, but it may be due to alterations in lifestyle because of the adoption of modern behavior norms, and an intention to avoid tanning (particularly females) are probable factors for the reduction in sun exposure and choosing sunscreen as a most effective approach of mitigating skin tanning in the female students.

In the present study, girls who used sunscreen compared to those who did not use sunscreen were more likely to have lower Vit D levels. In a recent systematic review of 76 studies, the evidence of experimental studies support the theoretical risk which sunscreen use may have on Vit D status, while the weight of findings from field trials and observational surveys indicates that the risk is low [44]. In the Muslim women, face and hands are the only body surfaces exposed to sun. So, sunscreen use and fully covering their body can put their health at risk. AlSaleh and co-workers reported the high prevalence of Vit D among Saudi girls compared to boys due

Table 3 Sunscreen usage of participants $(n=441)$

\begin{tabular}{|c|c|c|c|c|}
\hline Question items & Response & Number (\%) & $\begin{array}{l}\text { Vitamin D level } \\
\text { (ng/ml) }\end{array}$ & $P$ value* \\
\hline \multirow[t]{3}{*}{ How often do you use sunscreens? } & Only morning & $286(30.42)$ & $6.2(3.9-9.5)$ & 0.96 \\
\hline & Twice a day & $129(13.72)$ & $6.1(3.1-9.1)$ & \\
\hline & Thrice a day & $26(2.76)$ & $6.9(3.0-9.6)$ & \\
\hline \multirow[t]{3}{*}{ In which season do you use sunscreens? } & Only summer & $131(13.93)$ & $5.9(3.7-90)$ & 0.82 \\
\hline & Spring \& summer & $81(8.61)$ & $6.4(3.8-10.0)$ & \\
\hline & All season & $230(24.46)$ & $6.2(3.7-9.5)$ & \\
\hline \multirow[t]{4}{*}{ Sun protection factor (SPF) } & $<30$ & $82(8.83)$ & $6.7(4.9-9.2)$ & 0.11 \\
\hline & $30-50$ & $123(13.08)$ & $6.6(4.1-10.1)$ & \\
\hline & $>50$ & $87(9.25)$ & $5.5(3.0-9.4)$ & \\
\hline & No idea & $148(15.74)$ & $5.7(3.4-9.0)$ & \\
\hline \multirow[t]{3}{*}{ What location do you use sunscreens? } & Only face & $314(33.4)$ & $6.2(3.7-9.3)$ & 0.73 \\
\hline & Face \& hands & $124(13.19)$ & $6.4(4.0-9.2)$ & \\
\hline & Most of the body & $3(0.31)$ & $3.1(3.0-29.7)$ & \\
\hline
\end{tabular}

* Serum vitamin D levels expressed as median (IQR) and compared by using Kruskal Wallis test 
to the double negative effects of sunscreen using and clothed their body fully during sun exposure [45].

Our results did not show a significant association between the knowledge of the participants about Vit $\mathrm{D}$ and serum levels and dietary intake of Vit D. Similarly, no significant relationship was found between Vit D levels with nutritional status and daily living habits in private university students in Selangor and Saudi Arabia [46, 47]. Additionally, sun exposure over the previous week, sunscreen usage, oily fish consumption was not found to be associated with Vit D status among pregnant women [48]. As for our study and previous research, no statistically significant relationship was found between serum levels and dietary intake of Vit D with knowledge of Vit D, either before, or after adjustment for potential confounder in Saudi premenopausal women [49]. Interestingly, in a study including 1044 from the general population in Kuwait, $80 \%$ of people were found to have adequate knowledge; although Vit D deficiency remained prevalent among them [50]. In present study, the lack of association between knowledge and Vit D levels may be attributable to the high prevalence of Vit D deficiency in our population. Moreover, the less aware about Vit D food sources is also troubling among our participants.

Whilst knowledge and awareness play an important role in reducing the burden of any disorders, analysis of knowledge of Vit D suggests that doctors and health professionals must be especially careful in providing advice to people with these demographic characteristics. They require full information in order to make any lifestyle changes. The government and policy makers should consider how to improve the prevalence of Vit D deficiency through the use of mass media to promote awareness toward Vit D as well the need to test for Vit $\mathrm{D}$ and treat Vit $\mathrm{D}$ deficiency.

Our findings should be interpreted within the context of the study's strengths and limitations. This study surveyed a large population of girl students. Notably, serum 25OHD concentrations were measured in all participants, and information regarding dietary Vit D were collected. This allowed the association between knowledge and behaviors with respect to Vit D could be explored. One limitation of this study was that all the participants were adolescent female, which limits the generalizability of the results to the general population. Moreover, we did not collect data regarding outdoor activity/frequency/duration; so its relationship with Vit D levels was not possible. Since the study was performed in the Iranian population, whose religion, lifestyle and cultural background may be different from other populations, the our findings may not be comparable to studies in other parts of the world.

\section{Conclusion}

The majority of girls and young women possess inadequate knowledge about the major sources of Vit D, and its deficiency-related health disorders. However, surprisingly, the levels of serum and dietary intake of Vit D were not significantly different for those who had knowledge about the importance of Vit D consumption with those who did not. Public health education, such as workshops or training programs should be developed for the prevention of Vit D deficiency in the Iranian population especially in young girls who are more predisposed to Vit D deficiency.

\section{Abbreviations}

IQR: Interquartile range; FFQ: Food frequency questionnaire; NS: Nonsignificant; SPF: Sun protection factor; UV: Ultraviolet; Vit D: Vitamin D; 25OHD: 25-hydroxy vitamin D

\section{Supplementary Information}

The online version contains supplementary material available at https://doi. org/10.1186/s12889-021-12133-5.

Additional file 1: Supplementary File 1. Questionnaire on knowledge regarding vitamin D and sunscreen use. The questionnaire comprised of three sections. Section 1 comprised questions on demographic information. Section 2 concerned questions about behavior towards the usage of sunscreen. Section 3 was designed to evaluate the knowledge of participants about vitamin D.

\section{Acknowledgments}

We would like to thank the all participants and their parents.

\section{Authors' contributions}

$\mathrm{AB}$ and $\mathrm{ZF}$ conceived the study design, participated in the data collection and drafted the initial manuscript. PH and GF designed the study, undertook statistical analysis and interpretation and edited the paper. MG was responsible for participant recruitment and participated in data collection. All authors approved the final manuscript.

\section{Authors' information}

Afsane Bahrami has PhD degree of Molecular Medicine and has expertise in drug and vitamin analysis by HPLC. Also, she studies menstrual problems in adolescents and young women.

Zahra Farjami: She is researcher assistant of human genetics and is interested particularly in the genetic susceptibility of human disease. Gordon A. Ferns has a DSC, MD, MRCS, FRCP, FRCPath, EuSpLM, FRSA, and SFHEA. He is a professor of Medical Education and Metabolic Medicine and Head of the Department of Medical Education, Brighton and Sussex Medical School.

Parichehr Hanachi has PhD of clinical biochemistry and currently works at the Department of Biotechnology, Alzahra University.

Majid Ghayour-Mobarhan has an MD and PhD in Nutrition. He is a full Professor of Clinical Nutrition, Director of the Department of New Sciences and Technology and the founding member of Cardiovascular Research Center, Mashhad, Iran. His research interest is in atherosclerosis, from laboratory science to clinical studies.

\section{Funding}

This study was funded by Mashhad University of Medical Sciences (grant nu\#931188). The funding bodies had no role in any of the design, collection, analysis, interpretation of data, writing of the manuscript or decision to submit for publication. 


\section{Availability of data and materials}

The datasets used and/or analyzed during the current study are available from the corresponding author on reasonable request.

\section{Declarations}

\section{Ethics approval and consent to participate}

The study was approved by the Ethics Committee of Mashhad University of Medical Sciences (MUMS) (931188). All participants and their parents gave written informed consent to be interviewed, for the interviews to be audio recorded and used for research purposes and publication.

\section{Consent for publication}

Not applicable as no personal data was used in this article.

\section{Competing interests}

The authors declare that they have no competing interests.

\section{Author details}

'Clinical Research Development Unit of Akbar Hospital, Faculty of Medicine, Mashhad University of Medical Sciences, Mashhad, Iran. ${ }^{2}$ Clinical Research Development Unit, Imam Reza Hospital, Faculty of Medicine, Mashhad University of Medical Sciences, Mashhad, Iran. ${ }^{3}$ Metabolic Syndrome Research Center, Mashhad University of Medical Sciences, Mashhad, Iran. ${ }^{4}$ Brighton \& Sussex Medical School, Division of Medical Education, Falmer, Brighton, Sussex BN1 9PH, UK. ${ }^{5}$ Department of Biotechnology, Faculty of Biological Science, Alzahra University, Tehran, Iran.

Received: 27 September 2020 Accepted: 29 October 2021 Published online: 10 November 2021

\section{References}

1. Holick MF. Sunlight and vitamin D for bone health and prevention of autoimmune diseases, cancers, and cardiovascular disease. Am J Clin Nutr. 2004;80(6):1678S-88S. https://doi.org/10.1093/ajcn/80.6.1678S.

2. Cantorna MT, McDaniel K, Bora S, Chen J, James J. Vitamin D, immune regulation, the microbiota, and inflammatory bowel disease. Exp Biol Med. 2014;239(11):1524-30. https://doi.org/10.1177/1535370214523890.

3. Pittas AG, Dawson-Hughes B, Li T, van Dam RM, Willett WC, Manson JE, et al. Vitamin $D$ and calcium intake in relation to type 2 diabetes in women. Diabetes Care. 2006;29(3):650-6. https://doi.org/10.2337/diacare.29.03.06. dc05-1961.

4. Autier P, Gandini S. Vitamin D supplementation and total mortality: a metaanalysis of randomized controlled trials. Arch Intern Med. 2007;167(16): 1730-7. https://doi.org/10.1001/archinte.167.16.1730.

5. Pilz S, März W, Wellnitz B, Seelhorst U, Fahrleitner-Pammer A, Dimai HP, et al. Association of vitamin D deficiency with heart failure and sudden cardiac death in a large cross-sectional study of patients referred for coronary angiography. J Clin Endocrinol Metabol. 2008;93(10):3927-35. https://doi.org/10.1210/jc.2008-0784.

6. Sacerdote A, Dave P, Lokshin V, Bahtiyar G. Type 2 diabetes mellitus, insulin resistance, and vitamin D. Curr Diab Rep. 2019;19(10):101. https://doi.org/1 0.1007/s11892-019-1201-y.

7. Illescas-Montes R, Melguizo-Rodríguez L, Ruiz C, Costela-Ruiz VJ. Vitamin D and autoimmune diseases. Life Sci. 2019;233:116744. https://doi.org/10.101 6/j.lfs.2019.116744.

8. ARORA H, DIXIT V, SRIVASTAVA N. EVALUATION OF KNOWLEDGE, PRACTICES OF VITAMIN D AND ATTITUDE TOWARD SUNLIGHT AMONG INDIAN STUDENTS. EVALUATION. 2016:9(1).

9. Ho-Pham L, et al. Vitamin D status and parathyroid hormone in a urban population in Vietnam. Osteoporos Int. 2011;22(1):241-8. https://doi.org/10.1 007/s00198-010-1207-4.

10. Van Schoor N, Lips P. Global overview of vitamin D status. Endocrinol Metab Clin. 2017;46(4):845-70. https://doi.org/10.1016/j.ecl.2017.07.002.

11. Tabrizi R, Moosazadeh M, Akbari M, Dabbaghmanesh MH, Mohamadkhani $M$, Asemi Z, et al. High prevalence of vitamin D deficiency among Iranian population: a systematic review and meta-analysis. Iranian journal of medical sciences. 2018;43(2):125-39.

12. Organization, W.H., Vitamin and mineral requirements in human nutrition: report of a joint FAO/WHO expert consultation, Bangkok, Thailand, 21-30 September 1998. 2004: World Health Organization.
13. Khadilkar A. Vitamin D deficiency in Indian adolescents. Indian Pediatr. 2010; 47(9):755-6. https://doi.org/10.1007/s13312-010-0110-6.

14. Alzaheb, R.A., The Prevalence of Hypovitaminosis D and Its Associated Risk Factors Among Women of Reproductive Age in Saudi Arabia: A Systematic Review and Meta-Analysis. Clinical Medicine Insights: Women's Health, 2018. 11: p. $1179562 \times 18767884$.

15. Yammine $\mathrm{K}, \mathrm{Al}$ Adham $\mathrm{H}$. The status of serum vitamin $\mathrm{D}$ in the population of the United Arab Emirates. EMHJ-Eastern Mediterranean Health Journal. 2016;22(9):682-6. https://doi.org/10.26719/2016.22.9.682.

16. Faghih S, Abdolahzadeh M, Mohammadi M, Hasanzadeh J. Prevalence of vitamin d deficiency and its related factors among university students in shiraz, Iran. Int J Prev Med. 2014;5(6):796-9.

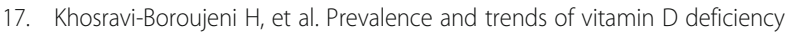
among Iranian adults: a longitudinal study from 2001-2013. J Nutr Sci Vitaminol. 2017;63(5):284-90. https://doi.org/10.3177/jnsv.63.284.

18. Farhud DD, Mehrabi A, Sarafnejad A, Sadeghipour HR, Rahimiforoushani A, Rokni MB, et al. A comprehensive, epidemiological and ecological descriptive study on vitamin d status in Iran (308005 people, from 20092018). Iran J Public Health. 2019;48(4):644-54.

19. Khayyatzadeh SS, Mirmoosavi SJ, Fazeli M, Abasalti Z, Avan A, Javandoost A, et al. High-dose vitamin D supplementation is associated with an improvement in several cardio-metabolic risk factors in adolescent girls: a nine-week follow-up study. Ann Clin Biochem. 2018;55(2):227-35. https:// doi.org/10.1177/0004563217707784

20. Farhood B, Geraily G, Alizadeh A. Incidence and mortality of various cancers in Iran and compare to other countries: a review article. Iran J Public Health. 2018;47(3):309-16.

21. Amori N, Aghajani M, Asgarian FS, Jazayeri M. Epidemiology and trend of common cancers in Iran (2004-2008). Eur J Cancer Care. 2017;26(5):e12449. https://doi.org/10.1111/ecc.12449.

22. Sung H, Ferlay J, Siegel RL, Laversanne $M$, Soerjomataram I, Jemal A, et al. Global cancer statistics 2020: GLOBOCAN estimates of incidence and mortality worldwide for 36 cancers in 185 countries. CA Cancer J Clin. 2021; 71(3):209-49. https://doi.org/10.3322/caac.21660.

23. Whiting, S.J. and M.S. Calvo, Vitamin D fortification and supplementation policies to correct vitamin D insufficiency/deficiency globally, in Vitamin D. 2018, Elsevier. p. 91-108.

24. Ahsan H, Parveen N, Khan NU, Hadi SM. Pro-oxidant, anti-oxidant and cleavage activities on DNA of curcumin and its derivatives demethoxycurcumin and bisdemethoxycurcumin. Chem Biol Interact. 1999: 121(2):161-75. https://doi.org/10.1016/S0009-2797(99)00096-4.

25. Kung AW, Lee K-K. Knowledge of vitamin D and perceptions and attitudes toward sunlight among Chinese middle-aged and elderly women: a population survey in Hong Kong. BMC Public Health. 2006;6(1):226. https:// doi.org/10.1186/1471-2458-6-226.

26. Arora H, Dixit V, Srivastava N. Evaluation of knowledge, practices of vitamin D and attitude toward sunlight among Indian students. Evaluation. 2016; 9(1):308.

27. Christie FT, Mason L. Knowledge, attitude and practice regarding vitamin D deficiency among female students in Saudi Arabia: a qualitative exploration. Int J Rheum Dis. 2011;14(3):e22-9. https://doi.org/10.1111/j.1756-185X.2011. 01624.x.

28. Moossavi M, Parsamanesh N, Bahrami A, Atkin SL, Sahebkar A. Role of the NLRP3 inflammasome in cancer. Mol Cancer. 2018;17(1):1-13. https://doi. org/10.1186/s12943-018-0900-3.

29. Bahrami A, Bahrami-Taghanaki H, Khorasanchi Z, Tayefi M, Ferns GA, Sadeghnia HR, et al. The association between neuropsychological function with serum vitamins $a, D$, and $E$ and hs-CRP concentrations. J Mol Neurosci. 2019;68(2):243-50. https://doi.org/10.1007/s12031-019-01288-x.

30. Martin, M.O., I.V. Mullis, and A.M. Kennedy, Progress in international Reading literacy study (PIRLS): PIRLS 2006 technical report. International Association for the Evaluation of Educational Achievement, 2007.

31. Bahrami A, Salarbashi D, Mohammad-Zadeh M, Tayefi M, Mirmoosavi SJ, Ferns GA, et al. Depression and aggression scores, reported sleep disorders status and their associated factors among adolescent girls in Northern Iran. Curr Psychol. 2019;40(10):1-12. https://doi.org/10.1007/ s12144-019-00429-0.

32. Esfahani $\mathrm{FH}$, et al. Reproducibility and relative validity of food group intake in a food frequency questionnaire developed for the Tehran lipid and glucose study. J Epidemiol. 2010;20(2):150-8. https://doi.org/10.2188/jea.JE2 0090083. 
33. Asghari G, Rezazadeh A, Hosseini-Esfahani F, Mehrabi Y, Mirmiran P, Azizi F. Reliability, comparative validity and stability of dietary patterns derived from an FFQ in the Tehran lipid and glucose study. Br J Nutr. 2012;108(6):110917. https://doi.org/10.1017/S0007114511006313.

34. Askari M, Abbaszadeh A, Saharkhiz M, Karbasi S, Talebpour A, Fashami AAA, et al. A study of the association between cognitive abilities and dietary intake in young women. Nutr Health. 2020;26(3):263-70. https://doi.org/1 $0.1177 / 0260106020940116$

35. Wat $W$, et al. Prevalence and impact of vitamin $D$ insufficiency in southern Chinese adults. Ann Nutr Metab. 2007;51(1):59-64. https://doi.org/10.1159/ 000100822.

36. Hawkins RC. 25-OH vitamin D3 concentrations in Chinese, Malays, and Indians. Clin Chem. 2009;55(9):1749-51. https://doi.org/10.1373/clinchem.2 009.129403.

37. Cashman KD, Hill TR, Cotter AA, Boreham CA, Dubitzky W, Murray L, et al. Low vitamin $D$ status adversely affects bone health parameters in adolescents. Am J Clin Nutr. 2008;87(4):1039-44. https://doi.org/10.1093/a jcn/87.4.1039.

38. Khan N. Attitudes and behavior towards sunlight exposure and knowledge about vitamin D among Omani female university students. EC Nutrition. 2017:8(2):35-42.

39. ASA RP, Abdalqader MA, Ghazi HF, Hasan TN, MDF F. Knowledge Regarding Vitamin D Among Private University Students in Malaysia. Ann Nutr Disord \& Ther. 2014;1(2):5.

40. Tariq A, Khan SR, Basharat A. Assessment of knowledge, attitudes and practice towards vitamin D among university students in Pakistan. BMC Public Health. 2020;20(1):1-10. https://doi.org/10.1186/s12889-020-8453-y.

41. Abboud M, Rizk R, Papandreou D, Hijazi R, al Emadi NE, Waszak PM. Evaluation of Self-Assessed State of Health and Vitamin D Knowledge in Emirati and International Female Students in United Arab Emirates (UAE). Front Psychol. 2020;1 1:1236. https://doi.org/10.3389/fpsyg.2020.01236.

42. AlGhamdi KM, AlAklabi AS, AlQahtani AZ. Knowledge, attitudes and practices of the general public toward sun exposure and protection: a national survey in Saudi Arabia. Saudi Pharmaceutical Journal. 2016;24(6): 652-7. https://doi.org/10.1016/j.jsps.2015.04.002.

43. Ho-Pham LT, Nguyen MT. Survey on knowledge and attitudes on vitamin D and sunlight exposure in an urban population in Vietnam. Journal of the ASEAN Federation of Endocrine Societies. 2012;27(2):191-5. https://doi.org/1 0.15605/jafes.027.02.10.

44. Neale $\mathrm{R}$, et al. The effect of sunscreen on vitamin D: a review. Br J Dermatol. 2019;181(5):907-15. https://doi.org/10.1111/bjd.17980.

45. Al-Saleh $Y$, et al. Vitamin D status in Saudi school children based on knowledge. BMC Pediatr. 2015;15(1):1-6. https://doi.org/10.1186/s12887-0150369-9.

46. binti Isa, A.S., T.N. Hasan, and H.F. Ghazi, Level of vitamin $d$ and its associated factors among private university students in shah alam, Selangor.

47. Mostafa RA. Assessment of vitamin D knowledge and awareness among female students of applied medical sciences faculty, Umm Al-Qura University. Asian Journal of Medicine and Health. 2020;18(2):23-32. https:// doi.org/10.9734/ajmah/2020/v18i230182.

48. Toher C, Lindsay K, McKenna M, Kilbane M, Curran S, Harrington L, et al. Relationship between vitamin D knowledge and 25-hydroxyvitamin D levels amongst pregnant women. J Hum Nutr Diet. 2014;27(3):261-9. https://doi. org/10.1111/jhn.12150.

49. Zareef TA, Jackson RT. Knowledge and attitudes about vitamin D and sunlight exposure in premenopausal women living in Jeddah, and their relationship with serum vitamin D levels. J Health Popul Nutr. 2021; 40(1):1-13.

50. Al-Mutairi N, Issa B, Nair V. Photoprotection and vitamin D status: A study on awareness, knowledge and attitude towards sun protection in general population from Kuwait, and its relation with vitamin D levels. Indian J Dermatol Venereol Leprol. 2012;78(3):342.

\section{Publisher's Note}

Springer Nature remains neutral with regard to jurisdictional claims in published maps and institutional affiliations.

\section{Ready to submit your research? Choose BMC and benefit from}

- fast, convenient online submission

- thorough peer review by experienced researchers in your field

- rapid publication on acceptance

- support for research data, including large and complex data types

- gold Open Access which fosters wider collaboration and increased citations

- maximum visibility for your research: over $100 \mathrm{M}$ website views per year

At BMC, research is always in progress.

Learn more biomedcentral.com/submissions 